Krasinsky Vladislav V., PHD in law,

the member of public scientifically-methodical

Council at the Central Electoral Commission of

Russian Federation

Красинский B.B. Участие организованных преступных групп в избирательных кампаниях // Политика и общество. 2008. № 4. С. 7-13; www.krasinskiy.ru

\title{
Participation of organized crime in election campaigns and problems of counteraction organized crime's penetration into organs of state and local power with the help of elections
}

Development of economic relations in the Russian Federation, which took place in the period of evident weakening of the regulative role of government in economy, the absence of necessary normative basis of market management, largescale division of state property with the use of illegal methods and tools led to massive involvement of organized crime in state economy. Step by step members of organized crime got control over most of economic agents. The fact that organized crime syndicates were interested in constant increase in their income, direct dependence of official and shadow economic activities on current politics in the Russian Federation, desire of organized crime figures to guarantee their personal safety caused the situation when leaders of criminal world wished to legalize their status and take active part in state level decision-making. Penetration of crime into organs of state and local government consisted of two stages.

The first stage shows the initial steps of criminals in their try to merge with politics of the country (1995-1999). During this period organized crime figures actively put their candidates forward into the organs of state and local government with the help of elections. This was possible because the legislation system and election laws until 1999 lacked any provisions mentioning that all people running as candidates had to inform election commissions about their criminal records. Rapid speed of organized crime's penetration into the government was closely connected with the changes in the structure of criminal world. Besides made men ("воры в законе" in the Russian slang), a new type of criminal leaders gained popularity. These were ruthless outlaws, criminals without any limits. They could be called "freaks", "frozen heads" ("отморозки") or "desperado" (“беспредельщики"). Those men ignored traditions of the criminal world. They were hostile to criminals from ethnic minorities of our country, neglected the ban to stay away from political and public life, committed murders and refused to pay fees to common criminal funds. In the 90 s this type of people from the criminal world was the most aggressive in getting posts in organs of state and local government with the help of elections.

Then organized crime figures legalized their status in organs of state and local government, got legal access to financial resources of the country and began using their state authority to perform crime activities. This stage reflects the final merge 
of organized crime with elements of the government machine and organs of local government in some regions of the Russian Federation.

The Russian Federation witnessed some new features. The State Duma deputies were now selected by proportional representation; there appeared to be legal restrictions on election candidates with outstanding convictions for serious, violent and extremist crimes; political parties reported on election campaigns financing in detail; legal liability for violation of election financing laws was toughened, a number of banking system institutions suspected of involvement in money laundering had their licenses revoked; corrupt leaders and representatives of state and local power successfully used their authority in the interests of organized crime groups; criminals didn't have to appear in government in person. All these caused the shift in tactics of organized crime figures when they tried to push their candidates into organs of power.

The statistics of regional and local elections, which took place in 2006 - 2007 shows the appearance of new methods and ways of organized crime's participation in election campaigns.

Firstly, the number of organized crime figures running for deputies or elective posts has reduced considerably. Now leaders of criminal world either offer candidates their financial assistance in election campaigns or prepare their own “clear' protégé (candidates without criminal record, who haven't discredited themselves by revealed contacts with organized crime syndicates).

Secondly, in spite of legalization of status and income, none of deputies or representatives of elective posts have dismissed their military units. As a rule, these groups work under cover of private security firms or security services. Thus, during pre-election and election period representatives of organized crime retain possibility to use coercive measures which if necessary can influence election process and state-level decision-making, they can also destabilize atmosphere in the country and frighten civilians. Besides, leaders of ethnic criminal groups operating on the territory of the Russian Federation can use their military units in clashes which appear between people of different nationalities in some regions of this country at regular intervals.

In the third place, taking into consideration the growing role of political parties in election process, the most important goals of criminal intelligence and counterintelligence are now to establish control over present political parties (regional branches of political parties) and to push their representatives into organs of state and local government with the help of political parties.

In the forth place, organized crime figures have given up money laundering in the period of elections. Criminals now have a great variety of legal ways of election campaign financing. Moreover, legal liability for violation of election financing law has toughened considerably.

Above mentioned strategy of criminals in election campaigns hampers purposeful activities of law enforcement services to prevent criminals from penetration into state and local government and increases social risk of such activities. Taking all this into account, we are sure that we need immediate and systematic implementation of a set of national (political, legal, personnel- 
organizational, informative-propagandistic) and special measures carried out by society and state power to prevent members of organized crime from putting their candidates forward into organs of state and local power with the help of election.

One of the examples of political measures to counteract organized crime's penetration into the government with the help of election is official missions of the Head of State and senior officials of the Russian Federation to heads of election committees and law enforcement services. The aim of such missions is to keep criminals away from political life of the country and to cut them off any possibility to be elected. Another example of possible federal and regional campaigns to counter the merge of organized crime with state and local power is "anticrime pacts" announced by political parties when federal and regional elections are going to take place. In July, 10, 2006, in Ekaterinburg representatives of "United Russia" Party, LDPR, CPRF, Russian Party of Pensioners, Russian Communist Labor Party, "Yabloko" Party, "Patriots of Russia" Party, Democratic Party of Russia and "Rodina" Party signed "Agreement of counteraction the organized crime's penetration into state power".

Legal measures to counteract organized crime activities to get state and local power must involve improvement of legislation system. Chances of candidates running for organs of state and local power who are on a federal 'wanted' list or who have any criminal records (including outstanding convictions) for serious offences must be limited. We suggest that Federal election law should have an obligatory duty for candidates running for deputies and / or elective posts to mention all their criminal records (including outstanding convictions), political parties and election commissions also have to inform the voters about the criminal records of candidates if they have any. In order to suppress unlawful activities and get data ready for bringing legal action against members of organized crime who were elected to organs of state and local power, we suggest using the institute of early termination of powers of deputies and elective posts when criminal cases according to articles of Criminal Code of the Russian Federation are opened. These articles provide tough sentences for serious and violent crimes and put these criminals on a 'wanted' list.

Organizational and personnel measures to counteract the organized crime must include two groups of measures. The first group of measures is connected with inter-party personnel policy i.e. vetting party nominee, detection of party corruption and passing gained information to law enforcement agencies, expulsion from political parties members who compromised themselves by links with extremist or terrorist organizations and organized crime syndicates. The second group of measures is connected with perfection of recruitment in the system of state power.

Informational measures and measures of propagation carried out by organs of state power and socially active members of the country in order to counteract the criminals' activities in election campaigns must increase legal competence of society. Election commissions, law enforcement agencies, organs of state power of the Russian Federation have to perform preventive actions aimed at the youth. We consider very important mass media activities to consolidate Russian society, to 
form negative attitude to organized crime actions, to criminal leaders, their intentions to take part in political life of the country and attempts to be elected to organs of state and local power.

Efficiency of state measures against election of criminals to the government is supplemented by special counteraction activities by law enforcement agencies. These activities involve enlisting middle and upper level members of organized crime to gain with their help information about plans and stuffing of the groups, about the representatives of state and local power who give assistance to criminals to perform illegal activities. These informants can reveal sources and channels of illegal financing of election campaigns and political activities that damage security of the Russian Federation. One of the important things is operative work in the near-criminal sphere in order to get information about the links between the candidates, that criminal groups are interested in, with functionaries of political parties, members of election commissions, members of law enforcement agencies. Operatives have to uncover the facts of corruption in political parties, nongovernmental organizations and organs of state and local power.

One more necessary measure is to document activities of criminals in order to prepare materials to bring legal action against leaders and members of organized crime syndicates. The final goal of all above-mentioned activities is complete termination of organized crime groups (criminals must be caught red-handed, arrested, legal actions must be brought against leaders and members of organized crime groups). Special sphere is to document activities of criminals having international links. In order to improve documentation process and to get ready for suitable counteraction measures we must develop relations and information exchange with Interpol, Coordination Bureau of Organized and Other Dangerous Types of Crime Control, foreign special services and law enforcement services. 